\title{
Comparative Study of the Effect of Temperature on the Corrosion Behaviour of 2205 Duplex Stainless Steel and 316 Austenitic Stainless Steel in Acidic Chloride Environment
}

\section{A. Olaseinde}

Advanced Materials and Electrochemical Research Group, Department of Metallurgical and Materials Engineering, Federal University of Technology, Akure, Nigeria

Email: adenikeseinde@yahoo.com

Received 20 January 2014; accepted 22 May 2015; published 26 May 2015

Copyright (C) 2015 by author and Scientific Research Publishing Inc. This work is licensed under the Creative Commons Attribution International License (CC BY). http://creativecommons.org/licenses/by/4.0/

\section{(c) (i) Open Access}

\section{Abstract}

The 2205 duplex stainless steel and 316 austenitic stainless steels were studied in 1 M sulphuric acid and $1 \% \mathrm{NaCl}$ solution. The microstructures of the specimens were investigated with scanning electron microscopy with energy dispersive X-ray analysis. X-ray Diffraction analysis was used for phase analysis. The electrochemical behaviour was evaluated using potentiodynamic method. The results show that the critical current density is higher for 316 austenitic stainless steels than 2205. The passive range was longer for 316 than 2205 at all the temperatures understudy. 2205 was found to have better corrosion resistance than 316 .

\section{Keywords}

Stainless Steels, Potentiodynamic, Acidic Chloride

\section{Introduction}

Stainless steels are steel with high percentages of chromium. The brightness of stainless steel is retained for long periods. It has different types which could be austenitic, ferritic, martensitic or duplex. The stainless steels possess an especially useful characteristic in resisting corrosion as they perform best under the oxidising conditions which are most harmful to ordinary steels and many of the non-ferrous alloys. Cold forming and cold rolling do 
not decrease the corrosion resistance. Duplex stainless steels (DSS) are family of steels having a two-phase microstructure with roughly the same volume fractions of ferrite and austenite. The advantageous properties of duplex stainless steels are based on the equilibrium of the microstructure [1]-[5]. The combination improved the mechanical properties and corrosion resistance of these steels [2]. The best performance of duplex stainless steel is obtained when the ferrite-austenite ratio is close to 50:50 [1]-[5]. Duplex stainless steel is used in petrochemical, desulphurization, pulp and papers, chemical tankers and architecture.

Austenitic stainless steels are Fe-based alloys with a chromium content of at least $10.5 \%$, its microstructure comprised primarily of austenite phase. It has good corrosion resistance and high toughness but they have high sensitivity to local corrosion in chloride environments. The 316 austenitic stainless steels contain between 16 18 wt percent Cr. It has been reported to have a very high corrosion resistance than grade 304 as a result of its high molybdenum content. This alloy is suitable for welding because it has carbon content lower than 301 to 303 series alloys [6] [7]. 316 are widely used in many industrial components, food preparation equipment particularly in chloride environments; it is used in architectural paneling, railings and trim, boat fittings, chemical containers and heat exchangers.

The 2205 have better corrosion resistance than low nickel duplex stainless steels [5] while the 316 had better corrosion resistance than most austenitic stainless steels.

This paper investigates the response of these two stainless steels in acidic chloride environments and also compares the effect of temperature on their corrosion behaviour.

\section{Experimental Methods}

The studied materials are EN.14462 (2205) duplex stainless steel and 316 austenitic stainless steels. They were supplied as plates with thickness of $6 \mathrm{~mm}$. the microstructural characterization was done by means of optical microscopy, scanning electron microscopy. Electrolytic etching in $40 \mathrm{~g} \mathrm{NaOH}$ in $100 \mathrm{ml}$ of distilled water was used for the 2205 to reveal its duplex microstructures. This treatment coloured the ferrite dark [8]. While for the 316 grade electrolytic etching with $10 \%$ oxalic acid was used.

Potentiodynamic polarization studies were carried out in a three electrode cell with graphite as counter electrode and $\mathrm{Ag} / \mathrm{AgCl}$ reference electrode; the samples were studied in $1 \mathrm{M}$ sulphuric acid and $1 \% \mathrm{NaCl}$ solution at $25^{\circ} \mathrm{C}, 40^{\circ} \mathrm{C}, 60^{\circ} \mathrm{C}$, and $80^{\circ} \mathrm{C}$. The temperatures were maintained with the aid of water baths.

The surfaces of the samples were prepared by grinding up to 800 grit. Potentials were scanned from -250 to $1200 \mathrm{mV}$ at a scan rate of $1 \mathrm{mV} / \mathrm{sec}$ with the aid of potentiostat with GPES 4.19 software, each test was repeated and good reproducibility was observed.

\subsection{Results and Discussion}

\subsubsection{Metallography}

The observations of the surfaces of the specimens were carried out using scanning electron microscopy. The SEM image of 316 austenitic stainless steel shows austenite structure and no other phases was observed as shown in Figure 1. The SEM image of 2205 duplex stainless steel is presented in Figure 2, showing austenite particles randomly dispersed in matrix of ferrite and are elongated along the rolling direction. Porosity was observed in the micrograph. Inter-metallic phases were not observed. The XRD analysis showed that the 2205 contains austenite and ferrites while the 316 contains only the austenite phase. A very wide band in the 2 Theta ranges 15 - 35 is usually observed with crystalline peaks. The wide band does not affect the peaks position or intensity.

\subsubsection{Potentiodynamic Curves}

Figure 3 show the potentiodynamic curves of 2205 and 316 stainless steels in $1 \mathrm{M}$ sulphuric acid and $1 \% \mathrm{NaCl}$ solutions at $25^{\circ} \mathrm{C}$. The corrosion potential of 2205 was $348 \mathrm{mV}$ which was nobler than $-255 \mathrm{mV}$ for 316 and this implies that 316 have more tendencies for corrosion than 2205 . The passive current density was $4.1 \times 10^{-6}$ $\mathrm{A} / \mathrm{cm}^{2}$ in 2205 and was lower than $1.08 \times 10^{-5} \mathrm{~A} / \mathrm{cm}^{2}$ in 316. The passive region is longer for 316 than 2205 . The $\mathrm{i}_{\text {crit }}$ value for 316 was $2.8 \times 10^{-5} \mathrm{~A} / \mathrm{cm}^{2}$ and is higher than $2.9 \times 10^{-6} \mathrm{~A} / \mathrm{cm}^{2}$ for 2205 duplex stainless steel. The length of the passive region is longer in 316 than for 2205. The critical current density of 2205 was lower than 316 at $25^{\circ} \mathrm{C}$.

The critical current density of 316 was $3.4 \times 10^{-4} \mathrm{~A} / \mathrm{cm}^{2}$ and is higher than $6.8 \times 10^{-5} \mathrm{~A} / \mathrm{cm}^{2}$ which is for 2205 ; 

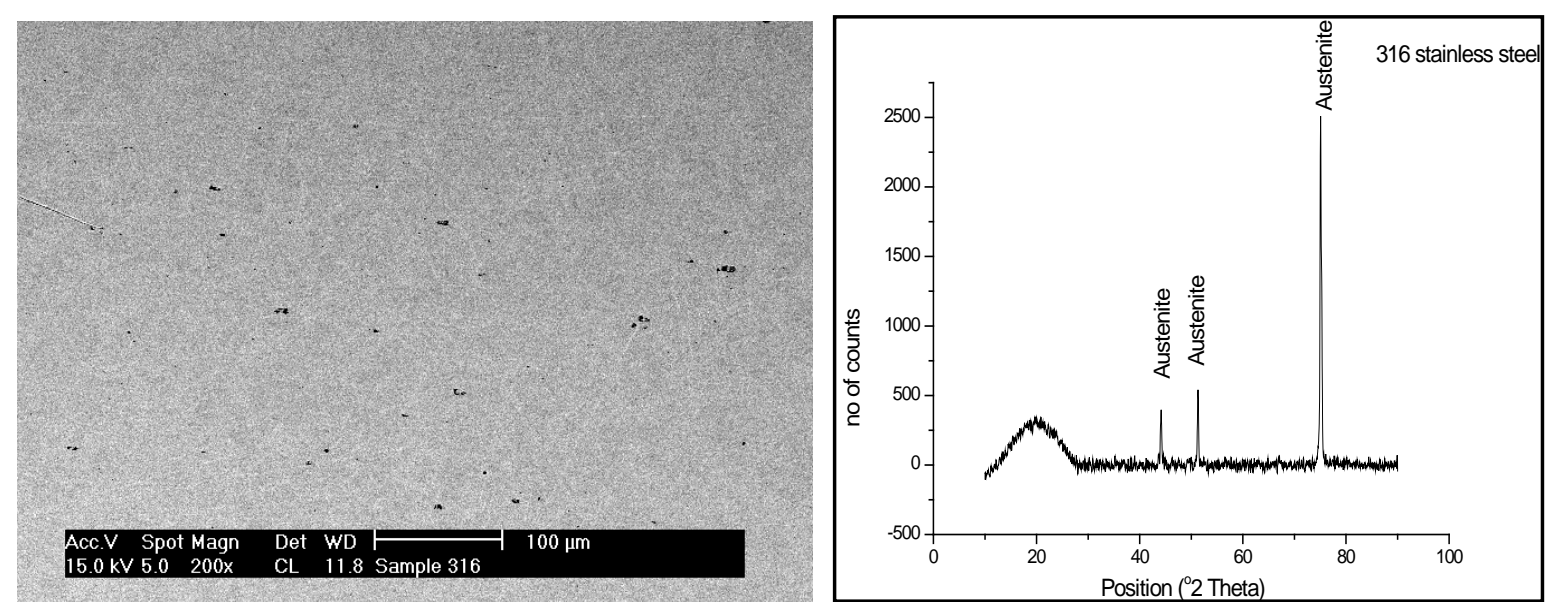

Figure 1. SEM-BSE image and X-ray Diffraction pattern of 316 austenitic stainless steel.
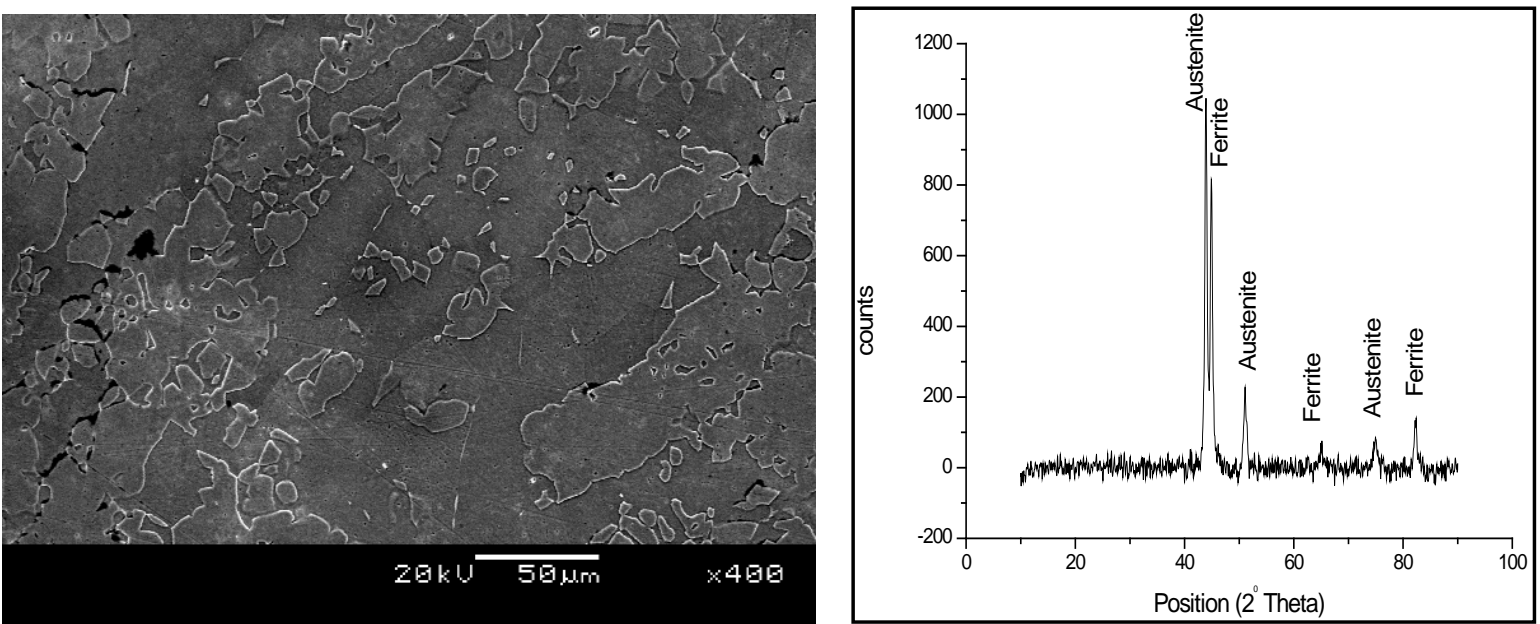

Figure 2. SEM-BSE image and X-ray Diffraction pattern of 2205 duplex stainless steel.

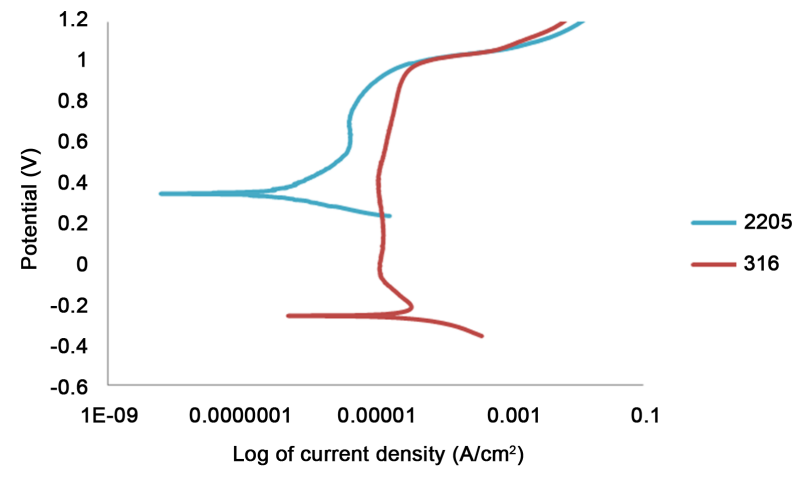

Figure 3. Polarization curves of 2205 and 316 stainless steel in $1 \mathrm{M}$ sulphuric acid $+1 \% \mathrm{NaCl}$ solutions at $25^{\circ} \mathrm{C}$.

the corrosion potential of 316 was $-225 \mathrm{mV}$ while for 2205 was $82 \mathrm{mV}$. The passive current density is lower in 316 than 2205, an active to passive transition was observed in the 316 at $40^{\circ} \mathrm{C}$ while displayed passivity (Figure 4).

The corrosion potential is nobler in 2205 than 316 at $80^{\circ} \mathrm{C}$ as shown in Figure 5; the critical current density in 316 was $1.6 \times 10^{-3} \mathrm{~A} / \mathrm{cm}^{2}$. The 2205 alloy exhibited passive behaviour. The high critical current density in 316 


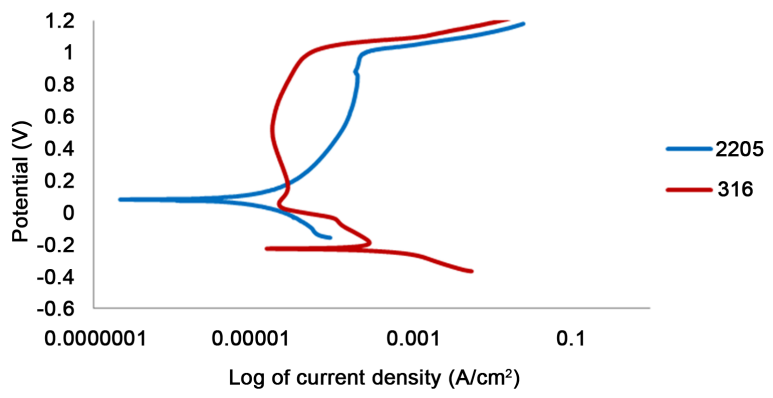

Figure 4. Polarization curves of 2205 and 316 stainless steel in $1 \mathrm{M}$ sulphuric acid $+1 \% \mathrm{NaCl}$ solutions at $40^{\circ} \mathrm{C}$.

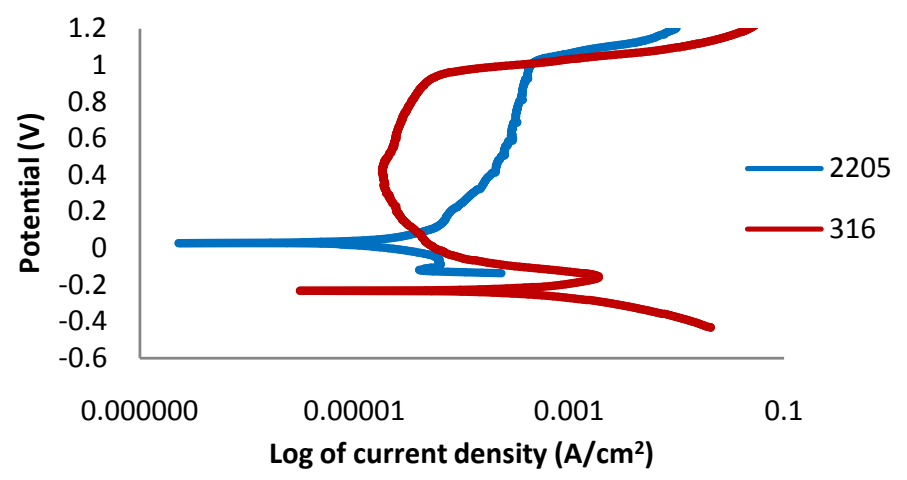

Figure 5. Polarization curves of 2205 and 316 stainless steel in $1 \mathrm{M}$ sulphuric acid $+1 \% \mathrm{NaCl}$ solutions at $80^{\circ} \mathrm{C}$.

could cause an increase in the corrosion rate of the sample than 2205. The $\mathrm{i}_{\text {pass }}$ is lower in 316 than in 2205 and the length of the passive region is lower than in 2205.

The increased in temperature increases the corrosion rates, the current density of 2205 duplex stainless steel in $1 \mathrm{M}$ sulphuric acid contaminated with $1 \% \mathrm{NaCl}$. Figure 6 showed that the corrosion of 2205 at $25^{\circ} \mathrm{C}$ was better than at higher temperature.

Type 316 gives useful service at room temperature in sulphuric acid, at elevated temperatures the corrosion rate increases. The increased in corrosion rates of type 316 in sulphuric acid is a function of concentration and temperature. Figure 7 showed that increasing the temperature shifted increases the critical current density and also increased the passive current density. The passivity ranges also decreases from 1064 at $25^{\circ} \mathrm{C}$ to 1044 at $80^{\circ} \mathrm{C}$. 316 showed active to passive transition at all temperatures.

The corrosion resistance exhibited by 2205 could be attributed to its dual structure. The high corrosion resistance is a major advantage of duplex stainless steels. Many researchers have concluded that duplex stainless steels have high corrosion resistance due to its dual phase [9]. The corrosion resistances of stainless steels have been correlated with their chemical composition [3] [10].

The pitting resistance equivalent (PREN) is calculated by PREN $=\% \mathrm{Cr}+3.3 \times \% \mathrm{Mo}+30 \times \% \mathrm{~N}-1 \times \% \mathrm{Mn}$

Therefore the PREN values for 2205 and 316 are 37.4 and 28.9 respectively. The PREN of 2205 is 8.5 higher than the PREN of 316. These indicate that 2205 have a higher pitting corrosion resistance than 316.

\section{Conclusion}

The electrochemical behaviours of 316 and 2205 stainless steel were studied in 1 M sulphuric acid contaminated by sodium chloride at different temperatures. The corrosion potential measurements show that the corrosion potential of 2205 was nobler than 316 at $25^{\circ} \mathrm{C}, 40^{\circ} \mathrm{C}$ and $80^{\circ} \mathrm{C}$. The potentiodynamic measurements indicated that at $25^{\circ} \mathrm{C}$ the passive current density of 2205 was lower than 316 . The passivity range in 316 was longer than for 2205 at the understudy temperatures. The passive current density was lower for 2205 at room temperature while at elevated temperature, it was lower for 316. The critical current density is higher for all samples of 316 . The 


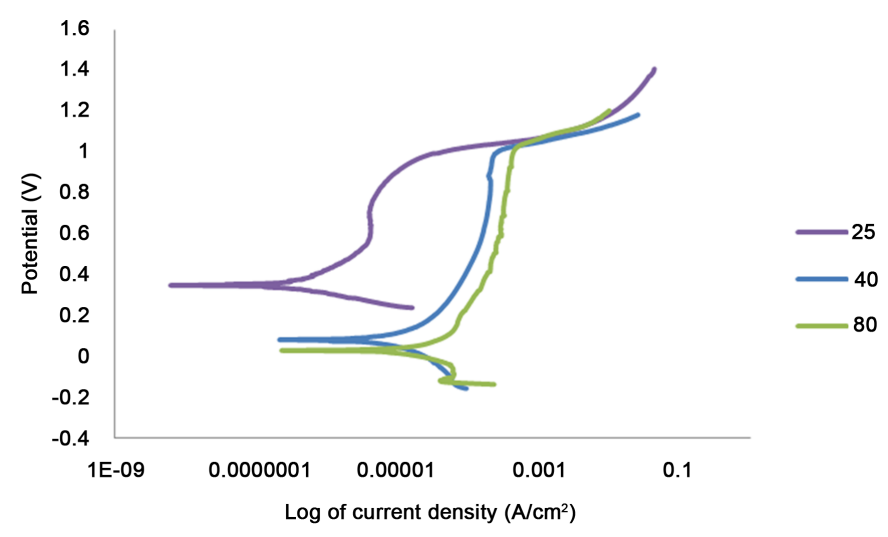

Figure 6. Potentiodynamic curves of 2205 duplex stainless steel in $1 \mathrm{M}$ sulphuric and $1 \% \mathrm{NaCl}$ solutions at different temperatures.

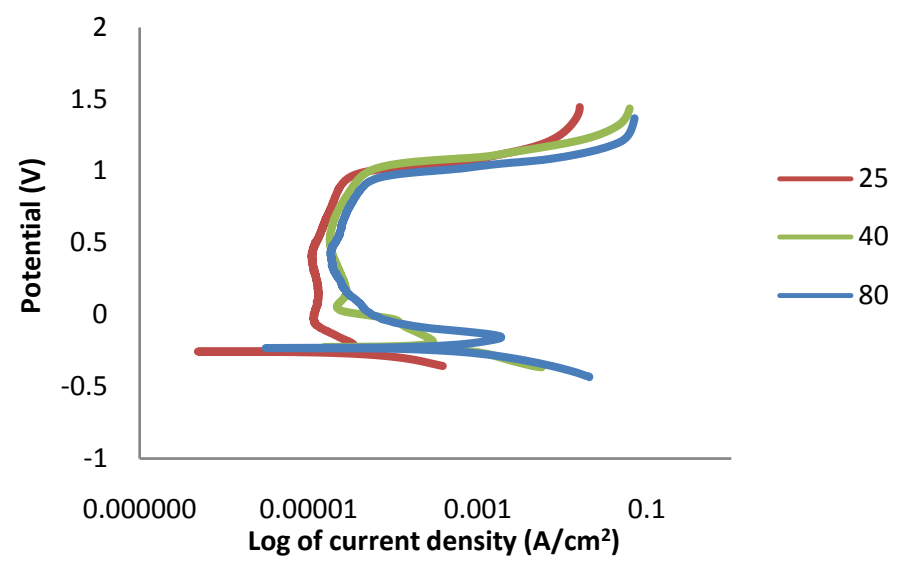

Figure 7. Potentiodynamic curves of 316 austenitic stainless steel in 1 $\mathrm{M}$ sulphuric and $1 \% \mathrm{NaCl}$ solutions at different temperature.

increase in temperature exhibited an increase in corrosion rates for the 2205 and 316 stainless steels. The 2205 duplex stainless steel showed a better corrosion resistance at $25^{\circ} \mathrm{C}$.

\section{Acknowledgements}

Science Initiative Group, Institute for Advanced Study, USA.

\section{References}

[1] Solomon, H.D. and Devine, T.M. (1983) Duplex Stainless Steels. American Society of Metals, Metals Park, Ohio, USA, 693-756.

[2] Desestret, A. and Charles, J. (2006) Stainless Steels. In: Lacombe, P., Baroux, B. and Beranger, G., Eds. Les Editions de Physique, Paris, 2006.

[3] Zhang, W., Jiang, L., Hu, J. and Song, H. (2008) Study of Mechanical and Corrosion Properties of a Fe-21.4Cr-6Mn1.5Ni-0.24N-0.6Mo Duplex Stainless Steel. Materials and Engineering A, 497, 501-504. http://dx.doi.org/10.1016/j.msea.2008.07.062

[4] Ibrahim, O.H., Ibrahim, I.S. and Khalifa, T.A.F. (2010) Effect of Aging on the Toughness of Austenitic and Duplex Stainless Steel Weldments. Journal of Materials Science \& Technology, 26, 810-816. http://dx.doi.org/10.1016/S1005-0302(10)60129-6

[5] Olaseinde, O.A., Van der Merwe, J. and Cornish, L. (2014) Characterization and Corrosion Behaviour of Selected Duplex Stainless Steels in Acidic and Acidic-Chloride Solution. Advances in Chemical Engineering and Science, 4, 89-93. http://dx.doi.org/10.4236/aces.2014.41012 
[6] Trillo, E.A. and Murr, L.E. (1999) Effects of Carbon Content, Deformation, and interfacial Energetics on Carbide Precipitation and Corrosion Sensitization in 304 Stainless Steel. Acta Materialia, 47, 235-245. http://dx.doi.org/10.1016/S1359-6454(98)00322-X

[7] Amudarasan, N.V., Palanikumar, K. and Shanmugam, K. (2013) Impact Behaviour and Micro Structural Analysis of AISI 316L Stainless steel Weldments. International Journal of Application or Innovation in Engineering \& Management, 2, 269-272.

[8] ASTM Designation: A923-06, Standard Test Methods for detecting Detrimental Intermetallic Phases in Duplex Austenitic/Ferritic Stainless Steel.

[9] Olsson, C.O.A. and Landolt, D. (2003) Passive Films on Stainless Steels: Chemistry, Structure and Growth. Electrochimica Acta, 48, 1093-1104. http://dx.doi.org/10.1016/S0013-4686(02)00841-1

[10] Solomon, H.D. and Devine Jr., T.M. (1982) Duplex Stainless Steels: A Tale of Two Phases. Conference of the Duplex Stainless Steels, ASM, Ohio, 693-756. 